\title{
TIME PRESENT AND TIME PAST: A DURATION ANALYSIS OF IMF PROGRAM SPELLS
}

\author{
by \\ Joseph P. Joyce* \\ Department of Economics \\ Wellesley College \\ Wellesley, MA 02481-8203
}

February 2002

Revised May 2003

\begin{abstract}
The programs of the International Monetary Fund were originally designed to provide short-term assistance to countries implementing policies to address balance of payments disequilibria. In recent decades, however, the Fund has instituted new facilities with longer time horizons, while many developing countries have adopted consecutive programs. As a result, the length of time spent by countries in IMF programs has grown. This paper analyzes the IMF program spells for a group of emerging economies over the period of 1982 to 2000. Duration models are used to investigate the time dependence of the failure rate of the spells and the factors that affect the duration of program spells. The hazard ratio of program spells has a non-monotonic shape, first rising and then falling over time. A spell's duration is independent of a previous spell length or the number of previous spells. Program duration is extended for those countries with lower percapita income, exports concentrated in primary goods, landlocked geographic status and autocratic regimes. Governments that are ideologically divided have shorter spells, which may reflect a breakdown in governance.
\end{abstract}

JEL: F33, O19

* Tel: 781-283-2160; Fax: 781-283-2177; Email: jjoyce@wellesley.edu 


\section{TIME PRESENT AND TIME PAST: A DURATION ANALYSIS OF IMF PROGRAM SPELLS*}

Time present and time past

Are both perhaps present in time future

And time future contained in time past

--T.S. Eliot, Four Quartets: Burnt Norton

\section{Introduction}

The International Monetary Fund was established after World War II to supervise and stabilize the international monetary system. It supports countries with balance of payments disequilibria by providing short-term credit, and the amount of time that a country could spend in a Fund program was originally limited. In recent decades, however, the Fund has instituted new programs with longer time horizons. Moreover, many developing countries have adopted consecutive programs. As a result, the length of time spent by countries in IMF programs has grown, and in some cases has extended over a decade.

The IMF has been criticized for the continued dependence of developing economies on its assistance. The Managing Director of the IMF, Horst Köhler, has acknowledged the criticism and pledged that "IMF facilities should be designed to discourage countries from getting used to IMF loans. ${ }^{11}$ However, while there have been a number of studies of the effectiveness of IMFsupported policies, ${ }^{2}$ less analysis has been undertaken on the length of time that countries spend in IMF programs. Consequently, the reasons that cause some nations to continue with successive Fund programs over extended periods of time are not well understood.

This paper analyzes IMF program spells for a group of developing economies over the period of 1982 to 2000. Previous studies have established that these countries have a continuing

\footnotetext{
* This paper has benefited from the comments of an anonymous referee.
} 
need for Fund resources due to recurring deficits and insufficient foreign exchange reserves. This paper extends this work to examine the factors that heighten this dependence. Duration models are used to investigate the time dependence of program spells and the factors that affect the length of these spells.

The reported results demonstrate that the hazard rate of Fund programs initially rises and then falls. This finding establishes that there is no institutional mechanism that terminates programs after a fixed length of time. The length of a program spell is independent of a previous spell's duration or the number of previous spells. In addition, program spells are extended in countries with structural features that accentuate their need for external assistance, while political characteristics also affect the length of the program spell.

The next section of the paper describes the institutional changes in the design of IMF programs and their time horizons. The following section provides an analysis of the factors that may affect the duration of program spells. The fourth section explains the methodology and data utilized in the paper. The fifth section presents the results of the empirical analysis, and the final section summarizes these results.

\section{IMF Programs}

The founders of the international monetary system established at Bretton Woods sought to avoid the destabilizing impact of the competitive depreciations of the prewar era by establishing rules governing external economic relations. IMF member countries pledged to defend par values of their currencies, which would only be changed in response to a "fundamental disequilbrium." In the event of a balance of payments crisis, a country could draw down the foreign exchange it had paid as part of its quota subscription. When that amount was 
exhausted, the IMF would supply a government with additional foreign exchange while it undertook adjustment policies to restore external balance. According to the Fund's Articles of Agreements, it would "...give confidence to members by making the general resources of the Fund temporarily available to them under adequate safeguards...,3

In the 1950s, the Stand-by Arrangement (SBA) emerged as the main instrument for providing financial resources to countries with balance-of-payment problems. ${ }^{4}$ The usual period of an SBA is one year to 18 months, consistent with the Fund's mandate to make short-term assistance available. The interest charge paid by the borrowing government is based on shortterm market rates, and the funds are to be repaid within five years. The actual provision of the IMF's support is linked to a government's agreement to undertake a program of specific macroeconomic measures designed to achieve external equilibrium, and its subsequent adherence to that program. The IMF monitors compliance with the approved policies through a process known as "conditionality," and only disburses credit as a government fulfills its obligations.

The breakdown of the Bretton Woods system in the 1970s allowed more flexibility in exchange rate agreements, while capital account liberalization provided the developed economies more access to private capital markets. The Fund's lending activities became concentrated among developing nations, and in response the IMF devised new programs with longer time horizons designed to foster reform and growth. ${ }^{5}$ In 1974, the Extended Fund Facility (EFF) was introduced to provide credit over a three-year period to countries that seek to rectify structural conditions that have led to balance of payments deficits, with a repayment period ranging from four to ten years. A country requesting an extended arrangement must present a plan of proposed structural adjustment policies, which may include the deregulation of domestic 
markets and the removal of barriers to trade and investment with other countries. As with the SBAs, the provision of assistance is linked to compliance with these policies.

The Structural Adjustment Facility (SAF), established in 1986, was targeted specifically toward low-income countries. Under this facility, the IMF provided assistance on concessional terms over a three-year period to countries that undertook economic policy reforms for the purpose of promoting macroeconomic stability and growth. It was succeeded in 1988 by the Enhanced Structural Adjustment Facility (ESAF), which provided assistance over a three to four year period. This program was renamed the Poverty Reduction and Growth Facility (PRGF) in 1999 in order to reflect the Fund's heightened emphasis on the elimination of poverty. These loans have an annual interest rate of 0.5 percent, and the repayments are to be made during the sixth to tenth year after disbursement. Countries receive assistance on a semiannual basis as they meet performance reviews of their proposed structural policies.

At the end of the last decade, the IMF enacted new lending facilities in response to the financial crises of the 1990s. The Supplemental Reserve Facility (SRF) allows the Fund to supplement its SBA and EFF arrangements in the event of an exceptional need for assistance due to a crisis in the financial markets, such as occurred in Asia in 1997. The Contingent Credit Line (CCL) was designed for countries that do not currently need assistance but are concerned about the possible fallout of a financial market crisis due to contagion effects, and want credit to be available if needed. A country qualifies for a CCL by meeting eligibility criteria based on its economic policies and performance. In both programs credit is available for up to one year, but there is a surcharge to the usual IMF rate of charge. The Fund also provides emergency assistance to countries that face natural disasters or conflict situations, or a temporary shortfall in export earnings. 
As a result of the design of the various programs instituted since the 1970 s, the amount of time that a country can spend in a Fund-supported program has been extended past one year. Moreover, many countries enter consecutive programs. The adoption of a new program reflects a need for additional resources, which may be due in part to the unfinished implementation of previous programs.

Compliance with a program's conditionality is often incomplete, and the amount of an IMF loan disbursed less than originally planned. Mussa and Savastano (2000) report that the actual amount of credit extended was less than half of the planned amounts in 37 percent of the 615 arrangements made between 1973 and 1997. They interpret the majority of these as "...cases where the program went off track because policies deviated significantly from those agreed with the IMF..." There is no penalty for noncompliance besides the incomplete disbursement of assistance, however, and a country may enter a new program. Consequently, many countries have agreed to a number of IMF arrangements since the 1970s and spend years in a series of consecutive Fund programs.

The extended nature of participation in IMF programs has been criticized on several grounds. The International Financial Institution Advisory Commission (2000), also known as the Meltzer Commission, asserted that the long-term nature of IMF programs demonstrates that they "...have not ensured economic progress," and actually "...often hindered the development of responsible, democratic institutions that correct their own mistakes and respond to changes in external conditions." ${ }^{77}$ The Overseas Development Council (2000) urged the IMF to cut back on its long-term lending and concentrate on short-term macroeconomic stabilization.

Despite these and other criticisms of the long-term duration of IMF programs, analysis of the reasons for extended program spells has been limited. Conway (2000) reported that a 
country's participation in an IMF program is associated with external sector crises of shorter duration, but continuing reliance on IMF programs diminishes this effect. In a study of the economic characteristics of frequent or "recidivist" borrowers from the IMF, Bird, Hussain, and Joyce (2003) found that such countries had relatively larger current account deficits, lower reserves and greater debt-service ratios. Vreeland (2003) has modeled the joint decisions of the IMF and a borrowing country to initiate a program and whether to continue it. He found that a country's decision to continue a program is influenced by its fiscal budget position and external debt service, while the IMF is more likely to continue programs in countries with lower holdings of foreign reserves. Conway (2003) reported that reserve holdings and the real exchange rate affect the length of program spells.

The IMF's recently instituted Independent Evaluation Office (IEO) selected the issue of extended borrowing from the Fund as the focus of its first report, Evaluation of Prolonged Use of IMF Resources (IMF 2002a). The report's authors found that prolonged use is a result of several factors, including the institution of new Fund programs with expanded goals. The report noted that frequent borrowing can have adverse consequences for both the borrowing country and the IMF, and proposed a number of measures to limit prolonged use. Mody and Saravia (2003) have found that frequent usage of Fund programs weakens the improved access to capital marketa that an IMF program usually entails.

Another focus of research on IMF programs has been the implementation of IMF programs. Recent studies by Edwards (2001), Ivanova, Mayer, Mourmouras and Anayiotas (2003) and Joyce (2003) have sought to identify the factors that affect the execution of the policies contained in the initial Letter of Intent and the subsequent disbursal of credit. These 
papers have found that political factors, such as the influence of special interest groups or a lack of political cohesion within a government, hinder the successful completion of a Fund program.

This paper bridges these two areas of research. Longer IMF program spells reflect a continuing need for external resources, as evidenced by the recurring deficits in the balance of payments of these countries. This may reflect structural characteristics of the economy, or political features that hinder the implementation of stabilization and reform policies. Identifying the factors that promote prolonged usage would assist the IMF in designing conditionality that is appropriate for a country, a goal listed in the Fund's recently issued "Guidelines on Conditionality" (2002b).

\section{Analysis of Program Spells}

The recurring use of IMF resources may be based on a country's structural economic characteristics. Poorer countries are most likely to enter IMF programs, because of both their need for credit and their lack of access to private capital markets. A more open economy is vulnerable to foreign shocks, but might also respond more quickly to measures designed to improve the current account. A reliance on exports of primary commodities would increase a country's vulnerability to falling export earnings due to a decline in the price of its primary export, and would also lower its response to a devaluation.

Geographic conditions can also be crucial. Gallup, Sachs and Mellinger (1999) and Mellinger, Sachs and Gallup (2000) have demonstrated that location and climate affect economic performance and policy choices. Tropical regions, for example, are adversely affected by the higher incidence of diseases such as malaria. Landlocked areas are disadvantaged in a number of ways, such as their lack of access to ocean transport, and consequently they are less likely to 
adopt open trade policies. Other factors specific to a particular geographic area can also affect the need for IMF resources.

The decision to enter and continue Fund programs, however, is essentially a political decision prompted by economic circumstances. In recent years economists have begun to consider the impact of political variables on the outcome of reform measures. Political factors have also been incorporated into models of IMF program selection as well as studies of program implementation.

The effect of more political freedom and public accountability on IMF program spells is ambiguous. On the one hand, reform policies may be more successful in an environment where the public can exercise a voice in designing such policies, and where public institutions are used to promote public welfare rather than private rent-seeking. However, a participatory and stable environment may also permit more resistance and delay, while allowing a government to continue but not complete an IMF program.

The cohesion of a government and its political strength can affect a country's ability to implement policies. Divided governments are unable to agree on stabilization and structural measures, and programs could end prematurely. Edwards and Tabellini (1991) reported that the success of stabilization programs is related to the political and institutional conditions of the countries where these measures are introduced.

A number of factors, therefore, may affect the duration of a country's participation in IMF programs. These structural and political variables may prolong or shorten a program spell. The duration of a spell reflects both the impact of time itself on participation in Fund programs and a country's characteristics. 


\section{Methodology and Data}

\subsection{Methodology}

Duration models are used to analyze events with time horizons, such as spells of unemployment or strikes. ${ }^{8}$ If $\mathrm{T}$ is a nonnegative random variable that represents the length of a spell and $\mathrm{X}$ is a vector of covariates associated with it, then the cumulative probability distribution of duration is the probability that the spell will end before time $\mathrm{t}$ :

$$
\mathrm{F}(\mathrm{t}, \mathrm{X})=\operatorname{Pr}(\mathrm{T}<\mathrm{t} \mid \mathrm{X})
$$

The corresponding density function is $\mathrm{f}(\mathrm{t}, \mathrm{X})$. The survivor function is the probability that a spell will last to or exceed time t:

$$
\begin{aligned}
\mathrm{S}(\mathrm{t}, \mathrm{X}) & =\operatorname{Pr}(\mathrm{T} \geq \mathrm{t} \mid \mathrm{X}) \\
& =1-\mathrm{F}(\mathrm{t}, \mathrm{X}) .
\end{aligned}
$$

The hazard function is the rate at which spells terminate at some time $t$, given that they have lasted to $\mathrm{t}$ :

$$
\begin{aligned}
\mathrm{h}(\mathrm{t}, \mathrm{X}) & =\lim _{\Delta \rightarrow 0} \frac{\operatorname{Pr}(\mathrm{t} \leq \mathrm{T} \leq \mathrm{t}+\Delta \mid \mathrm{T} \geq \mathrm{t}, \mathrm{X})}{\Delta} \\
& =\frac{\mathrm{f}(\mathrm{t}, \mathrm{X})}{\mathrm{S}(\mathrm{t}, \mathrm{X})}
\end{aligned}
$$

The hazard function possesses positive duration dependence if $\mathrm{dh}(\mathrm{t}, \mathrm{X}) / \mathrm{dt}>0$, and negative duration dependence if $\mathrm{dh}(\mathrm{t}, \mathrm{X}) / \mathrm{dt}<0$. A positive dependence indicates that the 
likelihood that a spell will end rises as its duration increases in length; a negative duration implies that the prospect that the spell will end decreases over time.

\subsection{Data}

A sample of 62 developing economies was used to obtain data on IMF program participation. The choice of countries and sample period was guided in part by the availability of data and the trade-off between breadth and depth of coverage. Countries with populations below one million and transition economies that joined the IMF in the 1990s were excluded from the sample, as were countries not included in the International Country Risk Guide (ICRG), which provides data for a large number of developing economies.

The Annual Reports of the IMF were consulted to identify programs initiated between 1982 and 1997, and extending through 2000. The regular credit programs, the SBAs and the EFF programs, as well as the concessional facilities for low-income countries, the SAFs and the ESAFs, were included. ${ }^{9}$ Program participation on a quarterly basis was measured by whether a country was enrolled in an IMF program for at least fifteen days during a quarter. A program spell (LEN) consists of the number of consecutive quarters enrolled in IMF programs.

The 62 countries in the sample accounted for 177 program spells, and 13 of these spells were right-censored, i.e., the programs were still operative at the end of the sample period. The mean spell length was 11.8 quarters, and the longest was 40 quarters and still continuing at the end of the period (Burkina Faso). Spells five years and longer in length are reported in Table 1. The countries in the sample, the dates and length of their program spells, and the types of programs that the countries entered are listed in the Appendix. 


\section{Results}

\subsection{Specification of Distribution}

In order to estimate duration models, a distribution of the data must be selected. The specification of the distribution determines the shape of the hazard function. Among the most commonly used in economics analysis are the Weibull distribution, which allows a rising or falling monotonic hazard rate; the exponential distribution, which yields a constant hazard function and can be considered a special case of the Weibull; and the log-logistic, which yields a non-monotonic hazard function which first increases and then decreases.

In order to choose a distribution, baseline exponential, Weibull, and log-logistic hazard functions were estimated, and ranked by the Akaike Information Criterion (AIC), where the preferred model is the one with lowest AIC value. ${ }^{10}$ The results are reported in Table 2. The loglogistic has a lower AIC value than the exponential and Weibull distributions, indicating that the shape of the hazard function is non-monotonic.

This finding is consistent with the data presented above on the length and distribution of spell lengths as well as the design of Fund programs, since most programs are intended to end after one to three years. The hazard ratio would rise under these circumstances, and then fall for those countries that continued with additional IMF programs. The use of the log-logistic distribution, therefore, is supported by the institutional conditions.

The survival function of the log-logistic distribution is specified as:

$$
\begin{aligned}
& \mathrm{S}(\mathrm{t})=\frac{1}{1+(\lambda \mathrm{t})^{\frac{1}{\sigma}}} \\
& \text { where } \lambda=\mathrm{e}^{-\mathrm{X}^{\prime} \beta}
\end{aligned}
$$

and the corresponding hazard function takes the form: 


$$
h(t)=\frac{\lambda^{\frac{1}{\sigma}}(t)^{1-\sigma}}{\sigma\left(1+(\lambda t)^{\frac{1}{\sigma}}\right)}
$$

The estimated value of $\sigma$ provides another test of the shape of the hazard function. If $\sigma<$ 1, the hazard has a non-monotonic shape, rising to a peak and then falling; if $\sigma>1$, the hazard function resembles a decreasing Weibull hazard. In the baseline log-logistic estimation used to calculate the AIC value, the estimated value of $\sigma$ was 0.41 with a standard error of 0.03 , confirming that the hazard rate is non-monotonic. Therefore, this distribution was chosen for the empirical work, although, as reported below, other distributions were utilized as a check of robustness.

The log-logistic model is an example of an accelerated failure-time model, where the survivor function for an individual spell, $S_{i}(t, X)$ is related to a baseline function $S_{0}(t)$ :

$$
\mathrm{S}_{\mathrm{i}}(\mathrm{t}, \mathrm{X})=\mathrm{S}_{0}(\mathrm{t} \Phi, \mathrm{X})
$$

where $\Phi$ is a constant that rescales time. In an accelerated failure-time model, the logarithm of time can be expressed as a linear function of the covariates:

$$
\ln (T)=X^{\prime} \beta+\sigma \varepsilon
$$

where $\varepsilon$ has a logistic distribution in the case of a log-logistic model. The coefficients are estimated through maximum likelihood estimation in order to take into account the censoring of the data. 


\subsection{Estimation of Covariates}

An implicit assumption of this class of model is that each spell is statistically independent. However, it is possible that the length of the spells may be related to each other. In order to take this possibility into account, two variables are included in each model: PNUM, the number of previous spells that occurred during the sample period, and PDUR, the length of a previous duration if one took place during the sample period. If either variable is positive and significant, then the incidence or length of previous spells would lead to longer spells in the future, and this could be construed as an indication that the programs were not successful in accomplishing their aims; conversely, negative and significant coefficients would indicate the opposite.

The sources of the data appear in the Appendix, and summary statistics appear in Table 3. The model was tested by introducing different sets of variables, beginning with the first set of explanatory variables; insignificant variables were dropped and significant variables kept as new variables were tested. The results are reported in Table 4. A positive parameter (negative) estimate indicates that the duration of a spell rises (falls) as the variable increases (decreases) in value.

A model with structural economic and geographic characteristics was estimated first. The variables are YCAP, per-capita real GDP in international prices; OPEN, exports and imports divided by GDP; PRIX, a dummy variable for economies where primary goods represent over 50 percent of total exports; TROP, a dummy variable for tropical countries; and LAND, a dummy variable for landlocked countries. The values of YCAP and OPEN in the year previous to the beginning of a program spell are used. In the initial estimations with all the variables included in one equation, the coefficients on the income and primary exports were significant at the ten 
percent level, while the landlocked status barely missed the cutoff. Since the primary exports and landlocked variables are correlated and both have an impact on income, the model was reestimated first with the income per capita variable and landlocked variables (Eq. 1), and then with the primary exports and openness variables (Eq. 2).

The results include the estimates of the distribution's shape parameter, $\sigma$. The reported values in Equations 1 and 2 are 0.37 and 0.38 with standard errors of 0.02 , consistent with the initial baseline estimates of 0.40 and 0.03 and the hypothesis that the hazard rate is nonmonotonic. The two variables included to account for the possible interdependency of the spells, PNUM and PDUR, are insignificant. There is no impact from the occurrence or length of previous spells on a spell's duration.

The coefficient on the per-capita income variable is negative and significant at the five percent level. Programs are more likely to end in a given period in a richer country for several reasons. First, the poorest nations have the most need for assistance and the least access to private capital flows. In addition, the poorest nations may have the most difficulty in completing the programs they enter. Finally, more IMF programs with longer time periods are available for these countries.

The landlocked variable is positive and significant. Countries that are landlocked have longer program spells. Radelet and Sachs (1998) and Gallup, Sachs and Mellinger (1999) point out that countries without coastal access are at a disadvantage in the processing of intermediate goods. Since shipping costs are higher, these countries will not be able to use their relative advantage in labor costs to promote manufactured exports.

The primary exports variable is positive, indicating that a country with a dependence on such exports is likely to spend more time in IMF programs. Primary exporters are susceptible to 
declining prices for their chief export, and less able to benefit from a devaluation. The finding that landlocked countries also have longer program spells is consistent with this finding. The IMF's (2002) econometric analysis of the characteristics of prolonged users also found that these countries had a higher concentration of primary exports.

The openness and tropical country variables are not significant in any of the specifications of the model.

Indicators of the type of political regime in power during the first year of the program were then included. The variables were introduced separately in Equations 3 and 4 in order to avoid collinearity. The variable POLITY is an indicator of relative democracy reported by the Polity IV Project, and ranges in value from +10 (high democracy) to -10 (high autocracy). The coefficient on the variable is negative and significant at the ten percent level.

The POLITY variable was then replaced with the combined Gastil indicators of political and civil rights, GASTIL, which are published by Freedom House. Each indicator ranges from one to seven, with higher values indicating fewer liberties. This variable was positive and also significant at the ten percent level, consistent with the previous result. The empirical results, therefore, provide evidence that democratic regimes spend less time in Fund programs, and are consistent with Vreeland's (2003) finding that dictatorships are more likely to continue IMF programs.

These results do not directly indicate whether the program spells ended because the programs were successful or for some other reason. However, other recent studies have examined the impact of democratic regimes on program completion and governance in general. Stone (2002) reported that the IMF is more likely to suspend programs in authoritarian countries, while Joyce (2003) found that program completion is higher in democratic regimes. Olson 
(1991) and Quinn and Wooley (2001) claim that democracies are more likely to have stable economic growth than autocracies, while Rivera-Batiz (2002) presents evidence that democracy has a positive effect on governance. The results reported in this study, therefore, are consistent with the results reported in the other studies.

The result for the parameter $\sigma$ is 0.38 in both estimations with a standard error of 0.02 . The coefficients for the two variables PNUM and PDUR are again insignificant.

The next set of variables examine the impact of accord within a government on program spells, using indicators for the first year of a program obtained from the World Bank's Database of Political Institution. ${ }^{11}$ The first, COH, is based on work of Roubini and Sachs (1989), and takes the value of zero when the same party controls the executive and legislative branches. It takes the value of one in a presidential system when the branches of government are split, and the values one, two or three when there are coalitions or minority governments in parliamentary systems. The second variable, POLAR, is based on an assignment of orientation values (left equals zero, center one and right-wing two) to the two veto players, and taking the absolute difference between these values. ${ }^{12}$ The variables are introduced separately in Equations 5 and 6.

The cohesiveness variable is positive but not significant. However, the polarization variable is negative and significant at the five percent level. Governments that are internally divided along ideological lines have shorter program spells.

This finding can be linked to the literature on the determinants of the completion of Fund programs. Edwards (2002) observed that IMF programs are more likely to be suspended in countries with fractionalized legislatures. Similarly, Ivanova, Mayer, Mourmouras and Anayiotas (2003) reported that a lack of political cohesion hindered the completion of an IMF program, while Joyce (2003) found that polarization was linked to lower rates of program 
completion. In view of those findings, the result reported here is most likely a reflection of a breakdown in governance and the ability to implement IMF programs.

The two duration dependency variables continued to be insignificant. The estimate of the $\sigma$ parameter is 0.38 in both equations, with a standard error of 0.03 .

\subsection{Robustness}

The robustness of the results was examined by reestimating the model using the partial likelihood estimation method of Cox (1972). This approach is often used to examine the effects of variables on a hazard rate without assuming a particular shape of the hazard function. In this class of model,

$$
\mathrm{h}\left(\mathrm{t}, \mathrm{X}, \mathrm{h}_{0}\right)=\theta(\mathrm{X}) \mathrm{h}_{0}(\mathrm{t})
$$

where $h_{0}(t)$ is a "baseline" hazard. The vector of parameters associated with $\mathrm{X}$ can be estimated without obtaining an estimate of the baseline hazard function. The coefficients show the impact on the baseline hazard of each of the covariates, and should have the opposite algebraic sign from those obtained from an estimation of an accelerated failure-time model such as the loglogistic. A higher (lower) hazard ratio results in a shorter (longer) duration.

The estimates of the coefficients from this semiparametric estimation and their impact on the hazard ratios are consistent with some, but not all, of the previous results. Those results that are significant at the 10 percent level in Table 4 are not significant here. An increase in per capita income raises the hazard function and consequently lowers the time spent in IMF programs. Landlocked countries have longer spells, but the significance of the primary goods export variable loses significance in this estimation. The algebraic signs of the coefficients of 
the two political regime variables, POLITY and GASTIL, are consistent with those reported in Table 4 but are no longer significant. The polarization variable, however, continues to be highly significant.

The lower levels of significance may reflect the difference in the specification of the models. The log-logistic model is a proportional odds model, as opposed to a proportional hazard model such as the Cox. ${ }^{13}$ Specifying a particular distribution for the hazard model may incorporate more information into the estimation that affects the results.

\section{Summary}

The span of time that countries spend in various IMF programs has lengthened in recent decades, and the IMF has come under criticism for allowing some countries to establish longterm relationships with the Fund. This paper presents the results of an analysis of the duration of these spells in a sample of developing economies and the factors that affect their length.

The average spell length was almost three years, but a number of spells lasted for five years or longer. The likelihood that a spell would end in a given period first rose as time passed, but then fell. This reflects the adoption by some countries of consecutive programs, and the lack of any penalty for failing to comply with a previous program's conditionality. The length of a Fund program spell was not affected by the number or length of previous spells.

Several factors affected the duration of these spells. Extended periods of program participation are more common in the poorest nations, which have the greatest need for official external assistance. Countries that are landlocked are more likely to continue with IMF programs, possibly because their geographic circumstances place them at an economic disadvantage. There is also evidence that countries that export predominantly primary 
commodities have longer spells; this finding is consistent with the hypothesis that they have not established a manufacturing base. Governments that are polarized along ideological lines end program spells more quickly, most probably due to incomplete implementation of the program. Finally, there is some evidence that democratic regimes spend less time in Fund programs, which is consistent with results that they are more successful in implementing the conditions associated with programs.

The IMF's recent emphasis on a country's "ownership" of a program depends in part on adapting stabilization and reform policies to a country's economic, political and social environment. The IMF's “Guidelines on Conditionality" (IMF 2002b) state that “... the Fund will pay due regard to the domestic social and political objectives, the economic priorities, and the circumstances of members, including the causes of their balance of payments problems and their administrative capacity to implement reforms." ${ }^{14}$ The results of this paper indicate that countries that use the Fund's resources on a long-term basis have characteristics that can be addressed. 


\section{NOTES}

${ }^{1}$ See IMF Survey, August 14, 2000.

${ }^{2}$ See Haque and Khan (1998) and Bird (2001) for surveys of the studies on the effectiveness of Fund-supported policies.

${ }^{3}$ Article I(v).

${ }^{4}$ See James (1996) for the historical origins of Fund programs.

${ }^{5}$ See Polak (1991) on the changes over time in the IMF's objectives and policies.

${ }^{6}$ Mussa and Savastano (2002), p. 94.

${ }^{7}$ See International Financial Institution Advisory Commission (2000), pp. 28-29.

${ }^{8}$ See Kiefer (1988) for a survey of this class of models.

${ }^{9}$ The IMF's lending facilities share many objectives, and the conditionality provisions also have similarities. Many poorer countries utilize both concessioanry and non-concessionary programs. Knight and Santaella (1997), Conway (2003) and Vreeland (2003) did not differentiate between the types of arrangements in their empirical analyses.

${ }^{10} \mathrm{AIC}=-2(\log$ likelihood $)+\left(\frac{2}{\text { sample size }}\right)($ number of estimated parameters $)$

${ }^{11}$ See Beck, Clarke, Groff, Keefer and Walsh (2000) for a description of the data.

12 The political regime variables were not included as they had only been significant at the $10 \%$ level.

${ }^{13}$ See Royston (2001) on the difference in hazard models.

${ }^{14}$ Decision No. I - Guidelines on Conditionality, A. 4. 
Table 1

Spells of Five Years or More

\begin{tabular}{|c|c|c|c|}
\hline Country & Dates & Length in Qtrs & Programs \\
\hline Egypt & 1993:IV - 1998:III & 20 & EFF, SBA \\
\hline Hungary & 1990:I - 1994:IV & 20 & SBA, EFF, SBA \\
\hline Cote D'Ivoire & 1984:III - 1989:II & 20 & $\operatorname{SBA}(4)$ \\
\hline Honduras & 1992:III - 1997:III & 21 & ESAF \\
\hline Kenya & 1988:I - 1993:I & 21 & SBA, SAF, ESAF \\
\hline Gambia, The & 1986:IV - 1991:IV & 21 & SBA, SAF, ESAF \\
\hline Ghana & 1995:III - 2000:IV & 22 & ESAF (2) \\
\hline Ghana & 1986:IV - 1992:I & 22 & SBA, EFF, SAF, ESAF \\
\hline Chile & 1985:III - 1990:IV & 22 & $\mathrm{EFF}, \mathrm{SBA}$ \\
\hline Madagascar & 1986:IV - 1992:II & 23 & SBA, SAF, SBA, ESAF \\
\hline Bolivia & 1995:I - 1900:IV & 24 & $\operatorname{ESAF}(2)$ \\
\hline Tunisia & 1986:IV - 1992:III & 24 & SBA, EFF \\
\hline Malawi & 1988:I - 1994:I & 25 & SBA, ESAF (2) \\
\hline Congo, Dem Rep & 1984:I - 1990:II & 26 & SBA (4), SAF, SBA \\
\hline Philippines & 1994:II - 2000:IV & 27 & SBA, EFF, SBA \\
\hline Pakistan & 1993:III - 2000:IV & 30 & SBA, EFF, SBA (2) \\
\hline Senegal & 1985:I - 1992:II & 30 & $\begin{array}{l}\text { SBA, EFF, ESAF, SBA, } \\
\text { ESAF, EFF, SBA }\end{array}$ \\
\hline Sri Lanka & 1988:I - 1995:III & 31 & SAF, ESAF \\
\hline Bolivia & 1986:II - 1994:II & 33 & SBA, SAF, ESAF \\
\hline Niger & 1983:IV - 1991:IV & 33 & SBA (4), SAF, ESAF \\
\hline Mali & 1992:III - 2000:IV & 34 & $\operatorname{ESAF}(3)$ \\
\hline Mozambique & 1987:II - 1995:IV & 35 & SAF, ESAF \\
\hline Jordan & 1992:I - 2000:IV & 36 & SBA, EFF (3) \\
\hline Guinea & 1991:IV - 2000:IV & 37 & ESAF (2) \\
\hline Jamaica & 1987:I - 1996:I & 37 & SBA (4), EFF \\
\hline Argentina & 1991:III - 2000:IV & 38 & SBA, EFF, SBA, EFF \\
\hline Burkina Faso & 1991:I - 1997:IV & 40 & SAF, ESAF (3) \\
\hline
\end{tabular}


Table 2

AIC Values for Hazard Rate Models

\begin{tabular}{ll}
\hline Distribution & AIC \\
\hline Exponential & 447.40 \\
Weibull & 414.66 \\
Log-logistic & 381.26 \\
\hline
\end{tabular}


Table 3

Summary Statistics of Data

\begin{tabular}{lrccc}
\hline Variable & Mean & Standard Deviation & Minimum & Maximum \\
\hline COH & 0.52 & 0.70 & 0 & 3 \\
GAST & 8.11 & 3.11 & 2 & 14 \\
LAND & 0.13 & 0.34 & 0 & 1 \\
LEN & 11.81 & 8.28 & 2 & 40 \\
OPEN & 54.05 & 23.79 & 6.32 & 142.41 \\
PDUR & 6.20 & 7.01 & 0 & 35 \\
PNUM & 1.25 & 1.27 & 0 & 6 \\
POLAR & 0.35 & 0.72 & 0 & 2 \\
POLITY & 0.92 & 6.92 & -9 & 10 \\
PRIX & 0.33 & 0.47 & 0 & 1 \\
TROP & 0.73 & 0.44 & 0 & 9695 \\
YCAP & 2429.37 & 1774.74 & 299 & \\
\hline
\end{tabular}


Table 4

Log-Logistic Model

\begin{tabular}{|c|c|c|c|c|c|c|}
\hline & Eq. 1 & Eq. 2 & Eq. 3 & Eq. 4 & Eq. 5 & Eq. 6 \\
\hline YCAP & $\begin{array}{l}\mathbf{- 0 . 0 0} \\
(0.00)\end{array}$ & - & - & - & - & - \\
\hline OPEN & - & $\begin{array}{c}0.00 \\
(0.00)\end{array}$ & - & - & - & - \\
\hline PRIX & - & $\begin{array}{c}\mathbf{0 . 3 8} \\
(0.11)\end{array}$ & $\begin{array}{c}\mathbf{0 . 2 5} \\
(0.12)\end{array}$ & $\begin{array}{c}\mathbf{0 . 2 4} \\
(0.12)\end{array}$ & $\begin{array}{c}\mathbf{0 . 2 6} \\
(0.12)\end{array}$ & $\begin{array}{c}0.22 \\
(0.12)\end{array}$ \\
\hline LAND & $\begin{array}{c}\mathbf{0 . 3 9} \\
(0.16)\end{array}$ & - & $\begin{array}{c}0.29 \\
(0.17)\end{array}$ & $\begin{array}{c}0.29 \\
(0.17)\end{array}$ & $\begin{array}{c}0.31 \\
(0.17)\end{array}$ & $\begin{array}{l}0.29 \\
0.17\end{array}$ \\
\hline TROP & $\begin{array}{c}0.06 \\
(0.13)\end{array}$ & - & - & - & - & - \\
\hline POLITY & - & - & $\begin{array}{l}-0.01 \\
(0.01)\end{array}$ & - & - & - \\
\hline GAST & - & - & - & $\begin{array}{c}0.03 \\
(0.02)\end{array}$ & - & - \\
\hline $\mathrm{COH}$ & - & - & - & & $\begin{array}{l}-0.06 \\
(0.07)\end{array}$ & - \\
\hline POLAR & - & - & - & & - & $\begin{array}{r}-\mathbf{- 0 . 1 6} \\
0.08\end{array}$ \\
\hline PNUM & $\begin{array}{l}-0.02 \\
(0.04)\end{array}$ & $\begin{array}{l}-0.02 \\
(0.04)\end{array}$ & $\begin{array}{c}0.01 \\
(0.05)\end{array}$ & $\begin{array}{c}0.00 \\
(0.04)\end{array}$ & $\begin{array}{l}-0.03 \\
(0.04)\end{array}$ & $\begin{array}{c}0.01 \\
(0.05)\end{array}$ \\
\hline PDUR & $\begin{array}{c}0.01 \\
(0.01)\end{array}$ & $\begin{array}{c}0.01 \\
(0.01)\end{array}$ & $\begin{array}{c}0.01 \\
(0.01)\end{array}$ & $\begin{array}{c}0.01 \\
(0.01)\end{array}$ & $\begin{array}{c}0.01 \\
(0.01)\end{array}$ & $\begin{array}{c}0.01 \\
(0.01)\end{array}$ \\
\hline $\mathrm{CON}$ & $\begin{array}{c}2.35 \\
(0.17)\end{array}$ & $\begin{array}{c}\mathbf{1 . 9 5} \\
(0.15)\end{array}$ & $\begin{array}{c}\mathbf{2 . 0 7} \\
(0.09)\end{array}$ & $\begin{array}{c}\mathbf{1 . 8 3} \\
(0.17)\end{array}$ & $\begin{array}{c}2.13 \\
(0.10)\end{array}$ & $\begin{array}{c}\mathbf{2 . 1 5} \\
(0.09)\end{array}$ \\
\hline$\sigma$ & $\begin{array}{c}0.38 \\
(0.02)\end{array}$ & $\begin{array}{c}0.39 \\
(0.02)\end{array}$ & $\begin{array}{c}0.38 \\
(0.02)\end{array}$ & $\begin{array}{c}0.38 \\
(0.02)\end{array}$ & $\begin{array}{c}0.38 \\
(0.03)\end{array}$ & $\begin{array}{c}0.38 \\
(0.03)\end{array}$ \\
\hline$\chi^{2}$ & 16.71 & 13.55 & 17.60 & 17.95 & 16.98 & 18.47 \\
\hline Log-likelihood & -180.27 & -180.80 & -179.20 & -179.66 & -172.86 & -168.49 \\
\hline Num of obs & 177 & 176 & 176 & 177 & 169 & 165 \\
\hline
\end{tabular}

Note: Standard errors are reported in parentheses. The $\chi^{2}$ statistic tests the hypothesis that all the estimated coefficients are equal to zero. Bold indicates significance at the 5\% level; italics indicates significance at the $10 \%$ level 
Table 5

Cox Model

\begin{tabular}{|c|c|c|c|c|c|c|}
\hline & Eq. 1 & Eq. 2 & Eq. 3 & Eq. 4 & Eq. 5 & Eq. 6 \\
\hline YCAP & $\begin{array}{c}\mathbf{0 . 0 0} \\
(0.00)\end{array}$ & - & - & - & - & - \\
\hline OPEN & - & $\begin{array}{l}-0.00 \\
(0.00)\end{array}$ & - & - & - & - \\
\hline PRIX & - & $\begin{array}{c}\mathbf{- 0 . 4 3} \\
(0.17)\end{array}$ & $\begin{array}{l}-0.23 \\
(0.19)\end{array}$ & $\begin{array}{l}-0.24 \\
(0.18)\end{array}$ & $\begin{array}{c}-0.24 \\
(0.19)\end{array}$ & $\begin{array}{l}-0.24 \\
(0.18)\end{array}$ \\
\hline LAND & $\begin{array}{l}\mathbf{- 0 . 5 0} \\
(0.25)\end{array}$ & - & $\begin{array}{l}-0.45 \\
(0.26)\end{array}$ & $\begin{array}{l}-0.44 \\
(0.26)\end{array}$ & $\begin{array}{l}-0.45 \\
(0.26)\end{array}$ & $\begin{array}{l}-0.46 \\
(0.26)\end{array}$ \\
\hline TROP & $\begin{array}{c}0.14 \\
(0.20)\end{array}$ & - & - & - & - & - \\
\hline POLITY & - & - & $\begin{array}{c}0.01 \\
(0.01)\end{array}$ & - & - & - \\
\hline GAST & - & - & - & $\begin{array}{l}-0.03 \\
(0.03)\end{array}$ & - & - \\
\hline $\mathrm{COH}$ & - & - & - & - & $\begin{array}{c}0.10 \\
(0.11)\end{array}$ & - \\
\hline POLAR & - & - & - & - & - & $\begin{array}{c}\mathbf{0 . 2 5} \\
(0.12)\end{array}$ \\
\hline PNUM & $\begin{array}{l}-0.01 \\
(0.07)\end{array}$ & $\begin{array}{c}0.03 \\
(0.07)\end{array}$ & $\begin{array}{l}-0.01 \\
(0.07)\end{array}$ & $\begin{array}{c}0.00 \\
(0.07)\end{array}$ & $\begin{array}{c}0.05 \\
(0.07)\end{array}$ & $\begin{array}{l}-0.01 \\
(0.07)\end{array}$ \\
\hline PDUR & $\begin{array}{l}-0.02 \\
(0.01)\end{array}$ & $\begin{array}{l}-0.02 \\
(0.01)\end{array}$ & $\begin{array}{l}-0.02 \\
(0.01)\end{array}$ & $\begin{array}{l}-0.02 \\
(0.01)\end{array}$ & $\begin{array}{l}-0.02 \\
(0.01)\end{array}$ & $\begin{array}{l}-0.02 \\
(0.01)\end{array}$ \\
\hline$\chi^{2}$ & 14.23 & 9.45 & 12.85 & 12.51 & 13.30 & 15.59 \\
\hline Log-likelihood & -713.06 & -710.13 & -708.39 & -713.92 & -675.82 & -653.64 \\
\hline Num of obs & 177 & 176 & 177 & 177 & 169 & 165 \\
\hline
\end{tabular}

Note: Standard errors are reported in parentheses. The $\chi^{2}$ statistic tests the hypothesis that all the estimated coefficients are equal to zero. Bold indicates significance at the $5 \%$ level; italics indicate significance at the $10 \%$ level. 
Figure 1

Distribution of IMF Program Spells

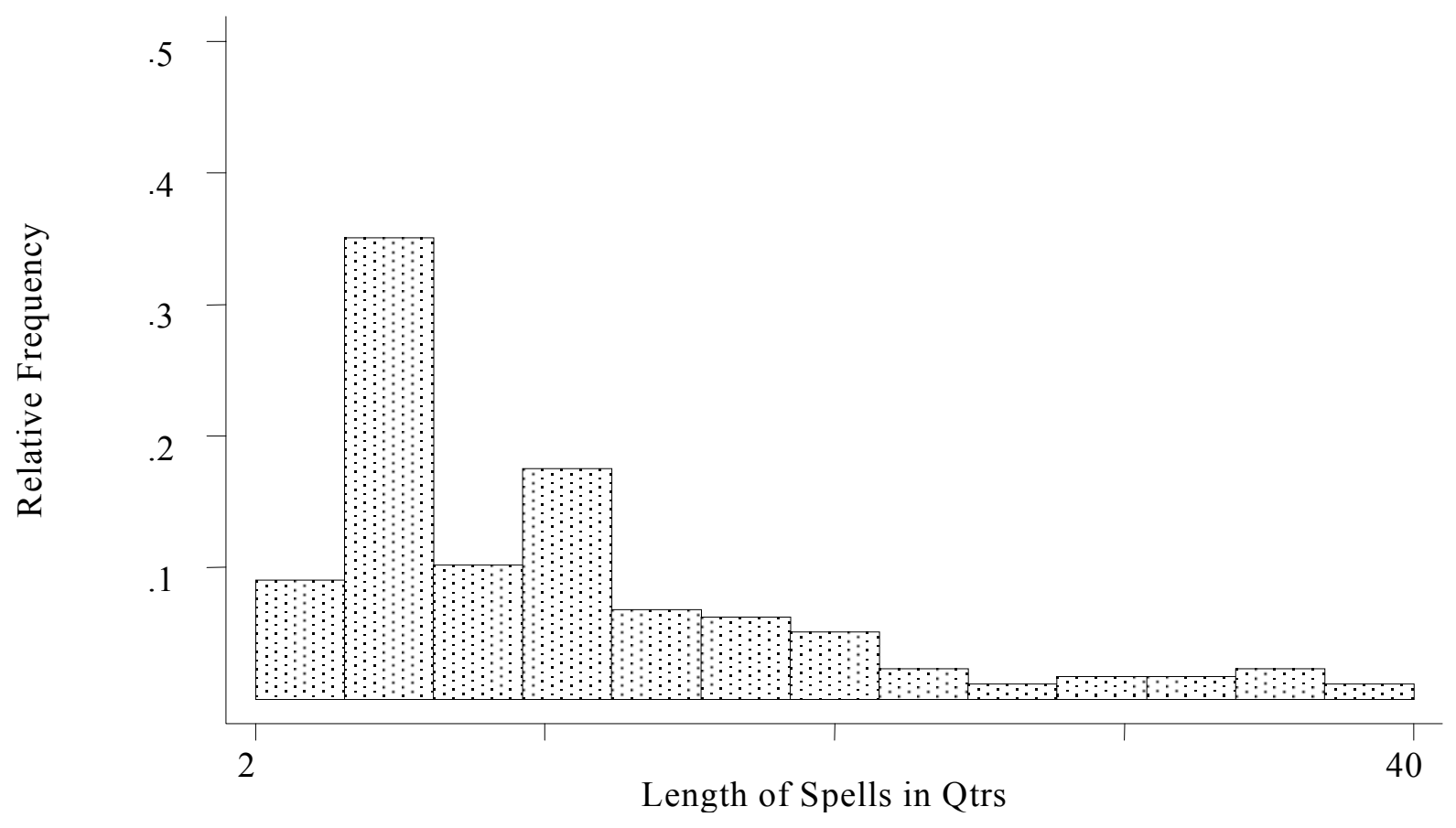




\section{Data Sources}

The variables used in the empirical analysis and their sources are:

COH Database of Political Institutions, World Bank

GAST Freedom House, Freedom in the World, various issues

LAND Bolivia, Burkina Faso, Democratic Republic of Congo, Hungary, Malawi, Mali, Niger, Uganda, Zambia, Zimbabwe

LEN IMF Annual Report, various issues

OPEN Global Development Network Growth Database

PDUR Length of previous duration, if applicable

PNUM Number of previous spells

POLAR Database of Political Institutions, World Bank

POLITY Polity IV Project

PRIX Global Development Network Growth Database

TROP Bolivia, Brazil, Burkina Faso, Cameroon, Democratic Republic of Congo, Republic of Congo, Costa Rica, Cote D'Ivoire, Dominican Republic, Ecuador, El Salvador, Ethiopia, Gabon, Gambia, Ghana, Guatemala, Guinea, Guinea-Bissau, Haiti, Honduras, Indonesia, Jamaica, Kenya, Madagascar, Malawi, Mali, Mexico, Mozambique, Nicaragua, Niger, Nigeria, Panama, Papua New Guinea, Peru, Philippines, Senegal, Sierra Leone, Sri Lanka, Tanzania, Thailand, Togo, Trinidad \& Tobago, Venezuela, Zambia, Zimbabwe

YCAP Penn World Table (Mark 5.6), updated by World Bank 
Appendix

IMF Program Spells

\begin{tabular}{|c|c|c|c|c|c|}
\hline Country & Dates & Qtrs & Country & Dates & Qtrs \\
\hline \multirow{3}{*}{ Algeria } & 1989:II - 90:II & 5 & Cote D'Ivoire & 1994:I - 97:II & 14 \\
\hline & 1991:II - 92:I & 4 & Dominican Rep. & 1983:I - 86:I & 13 \\
\hline & 1994:II - 98:II & 17 & & 1991:III - 93:I & 7 \\
\hline \multirow[t]{5}{*}{ Argentina } & 1983:I - 84:I & 5 & Honduras & 1992:III - 97:III & 21 \\
\hline & 1985:I - 86:II & 6 & Hungary & 1982:IV - 84:IV & 9 \\
\hline & 1987:III - 88:III & 5 & & 1988:II - 89:II & 5 \\
\hline & 1989:IV - 91:I & 6 & Dominican Rep. & 1993:III - 94:I & 3 \\
\hline & 1991:III - 2000:IV* & 38 & Ecuador & 1983:III - 84:III & 5 \\
\hline \multirow[t]{3}{*}{ Bangladesh } & 1983:II - 83:III & 2 & & 1985:I - 86:I & 5 \\
\hline & 1985:IV - 90:I & 18 & & 1986:III - 87:II & 4 \\
\hline & 1990:III - 93:III & 13 & & 1988:I - 89:I & 5 \\
\hline \multirow[t]{2}{*}{ Bolivia } & 1986:II - 94:II & 33 & & 1989:III - 91:I & 7 \\
\hline & 1995:I - 2000:IV* & 24 & & 1991:IV - 92:IV & 5 \\
\hline \multirow[t]{3}{*}{ Brazil } & $1983: \mathrm{I}-86: \mathrm{I}$ & 13 & & 1994:II - 95:IV & 7 \\
\hline & 1988:III - 90:I & 7 & Egypt & 1987:II - 88:IV & 7 \\
\hline & 1992:I - 93:III & 7 & & 1991:II - 93:II & 9 \\
\hline \multirow[t]{3}{*}{ Bulgaria } & 1991:I - 93:II & 10 & & 1993:IV - 98:III & 20 \\
\hline & 1994:II - 95:I & 4 & El Salvador & 1982:III - 83:III & 5 \\
\hline & 1996:III - 98:II & 8 & & 1990:III - 91:III & 5 \\
\hline Burkina Faso & 1991:I - 2000:IV* & 40 & & 1992:I - 94:IV & 12 \\
\hline \multirow[t]{4}{*}{ Cameroon } & 1988:IV - 90:II & 7 & & 1995:III - 96:III & 5 \\
\hline & 1992:I - 92:III & 3 & & 1997:I - 98:II & 6 \\
\hline & 1994:I - 96:III & 11 & Ethiopia & 1992:IV - 95:IV & 13 \\
\hline & 1997:III - 2000:III & 13 & & 1996:IV - 99:IV & 13 \\
\hline \multirow[t]{2}{*}{ Chile } & $1983: I-84: I V$ & 8 & Gabon & 1987:I - 88:IV & 8 \\
\hline & 1985:III - 90:IV & 22 & & 1989:III - 91:I & 7 \\
\hline Congo, Dem. Rep. of & 1984:I - 90:II & 26 & & 1991:IV - 93:I & 6 \\
\hline \multirow[t]{4}{*}{ Congo, Rep. of } & 1986:III - 88:II & 8 & & 1994:II - 95:I & 4 \\
\hline & 1990:III - 92:II & 8 & & 1995:IV - 99:I & 14 \\
\hline & 1994:III - 95:II & 4 & Gambia & 1984:II - 85:II & 5 \\
\hline & 1996:III - 99:II & 12 & & 1986:IV - 91:IV & 21 \\
\hline \multirow[t]{5}{*}{ Costa Rica } & 1985:I - 86:I & 5 & Ghana & 1983:III - 85:IV & 10 \\
\hline & 1987:IV - 90:II & 11 & & 1986:IV - 92:I & 22 \\
\hline & 1991:II - 92:III & 6 & & 1995:III - 00:IV* & 22 \\
\hline & 1993:II - 94:I & 4 & Guatemala & 1983:III - 84:IV & 6 \\
\hline & 1995:IV - 97:I & 6 & & 1988:IV - 90:I & 6 \\
\hline \multirow[t]{3}{*}{ Cote D'Ivoire } & 1984:III - 89:II & 20 & & 1993:I - 94:I & 5 \\
\hline & 1989:IV - 91:II & 7 & Guinea & 1986:I - 87:I & 5 \\
\hline & 1991:IV - 92:III & 4 & & 1987:III - 90:III & 13 \\
\hline
\end{tabular}


IMF Program Spells (continued)

\begin{tabular}{|c|c|c|c|c|c|}
\hline Country & Dates & Qtrs & Country & Dates & Qtrs \\
\hline Guinea & 1991:IV - 2000:IV* & 37 & Mexico & 1995:I - 97:I & 9 \\
\hline \multirow[t]{2}{*}{ Guinea-Bissau } & 1987:IV - 90:IV & 13 & Morocco & 1983:IV - 85:I & 6 \\
\hline & 1995:I - 98:III & 15 & & 1985:III - 89:IV & 18 \\
\hline \multirow[t]{4}{*}{ Haiti } & 1982:III - 85:III & 13 & & 1990:III - 91:I & 3 \\
\hline & 1987:I - 90:IV & 16 & & 1992:I - 93:I & 5 \\
\hline & 1995:I - 96:I & 5 & Mozambique & 1987:II - 95:IV & 35 \\
\hline & 1996:IV - 99:IV & 13 & & 1996:III - 2000:IV* & 18 \\
\hline \multirow[t]{4}{*}{ Honduras } & 1982:IV - 83:IV & 5 & Nicaragua & 1991:IV - 93:I & 6 \\
\hline & 1990:III - 92:I & 7 & & 1994:III - 97:II & 12 \\
\hline & 1990:I - 94:IV & 20 & Niger & 1983:IV - 91:IV & 33 \\
\hline & 1996:I - 98:I & 9 & & 1994:I - 95:I & 5 \\
\hline \multirow[t]{2}{*}{ India } & 1991:I - 91:II & 2 & & 1996:II - 99:III & 14 \\
\hline & 1991:IV - 93:II & 7 & Nigeria & 1987:I - 88:I & 5 \\
\hline Indonesia & 1997:IV - 2000:IV* & 13 & & 1989:I - 90:II & 6 \\
\hline \multirow[t]{2}{*}{ Jamaica } & 1984:III - 86:III & 9 & Nigeria & 1991:I - 92:I & 5 \\
\hline & 1987:I - 96:I & 37 & Pakistan & 1989:I - 91:IV & 12 \\
\hline \multirow[t]{2}{*}{ Jordan } & 1989:III - 90:IV & 6 & & 1993:III - 2000:IV* & 30 \\
\hline & 1992:I - 2000:IV* & 36 & Panama & 1982:II - 84:IV & 11 \\
\hline \multirow[t]{4}{*}{ Kenya } & $1985: \mathrm{I}-86: \mathrm{I}$ & 5 & & 1985:III - 87:I & 7 \\
\hline & 1988:I - 93:I & 21 & & 1992:I - 94:III & 11 \\
\hline & 1994:I - 94:IV & 4 & & 1995:IV - 97:I & 6 \\
\hline & 1996:II - 99:II & 13 & & 1997:IV - 2000:IV* & 13 \\
\hline \multirow[t]{3}{*}{ Korea } & 1983:III - 85:I & 7 & Papua N. Guinea & 1990:II - 92:III & 10 \\
\hline & 1985:III - 87:I & 7 & & 1995:III - 97:IV & 10 \\
\hline & 1997:IV - 2000:IV & 13 & Peru & 1982:II - 85:II & 13 \\
\hline \multirow[t]{3}{*}{ Madagascar } & 1984:II - 86:II & 9 & & 1993:II - 96:I & 12 \\
\hline & 1986:IV - 92:II & 23 & & 1996:III - 99:I & 11 \\
\hline & 1996:IV - 2000:IV & 17 & Philippines & 1983:I - 84:I & 5 \\
\hline \multirow[t]{4}{*}{ Malawi } & 1982:III - 86:III & 17 & & 1984:IV - 86:II & 7 \\
\hline & 1988:I - 94:I & 25 & & 1986:IV - 88:III & 8 \\
\hline & 1994:IV - 95:II & 3 & & 1989:II - 93:I & 16 \\
\hline & 1995:IV - 99:IV & 17 & & 1994:II - 2000:IV & 27 \\
\hline \multirow[t]{4}{*}{ Mali } & 1983:IV - 85:II & 7 & Poland & 1990:I - 94:I & 17 \\
\hline & 1985:IV - 87:I & 6 & & 1994:III - 96:I & 7 \\
\hline & 1988:III - 91:III & 13 & Senegal & 1985:I - 92:II & 30 \\
\hline & 1992:III - 2000:IV* & 34 & & 1994:I - 97:IV & 16 \\
\hline \multirow[t]{3}{*}{ Mexico } & 1983:I - 85:IV & 12 & Sierra Leone & 1986:IV - 89:IV & 13 \\
\hline & 1986:IV - 88:I & 6 & & 1994:III - 98:II & 16 \\
\hline & 1989:II - 93:II & 17 & South Africa & 1982:IV - 83:IV & 5 \\
\hline
\end{tabular}


IMF Program Spells (continued)

\begin{tabular}{|c|c|c|c|c|c|}
\hline Country & Dates & Qtrs & Country & Dates & Qtrs \\
\hline Sri Lanka & 1988:I - 95:III & 31 & & 1990:IV - 92:I & 6 \\
\hline \multirow[t]{2}{*}{ Tanzania } & 1991:III - 94:III & 13 & & 1992:III - 93:II & 4 \\
\hline & 1996:IV - 2000:IV* & 17 & & 1996:I - 97:I & 5 \\
\hline \multirow[t]{2}{*}{ Thailand } & 1985:II - 86:IV & 7 & & 1997:III - 2000:IV* & 14 \\
\hline & 1997:III - 00:II & 12 & Venezuela & 1989:III - 93:I & 15 \\
\hline Togo & 1994:IV - 98:II & 15 & & 1996:III - 97:II & 4 \\
\hline Trinidad \& Tobago & 1989:I - 91:I & 9 & Zambia & 1983:II - 87:II & 17 \\
\hline Tunisia & 1986:IV - 92:III & 24 & & 1995:IV - 98:II & 13 \\
\hline Turkey & 1994:III - 96:I & 7 & Zimbabwe & 1983:II - 84:III & 6 \\
\hline \multirow[t]{2}{*}{ Uruguay } & 1983:II - 85:II & 9 & & 1992:I - 95:III & 15 \\
\hline & 1985:IV - 87:I & 6 & & & \\
\hline
\end{tabular}

Note: $*$ denotes censored spell

Source: IMF Annual Report, various issues. 


\section{References}

Beck, Thorsten, George Clarke, Alberto Groff, Philip Keefer, and Patrick Walsh, "New Tools and New Tests in Comparative Political Economy," World Bank Development Research Group Policy Research Working Paper no. 2283, 2002.

Bird, Graham, "IMF Programs: Do They Work? Can They Be Made To Work Better?" World Development 29 (2001):1849-1865.

Bird, Graham, Mumtaz Hussain, and Joseph P. Joyce, "Many Happy Returns? Recidivism and the IMF," Journal of International Money and Finance, forthcoming (2003).

Conway, Patrick, "IMF Programs and Economic Crisis: An Empirical Study of Transition," Working Paper, Chapel Hill, NC: University of North Carolina at Chapel Hill, 2000.

Conway, Patrick, "Duration and Recidivism in IMF Programs; Evidence From the Period 19731992," Working Paper, Chapel Hill, NC: University of North Carolina at Chapel Hill, 2003.

Cox, David R., "Regression Models and Life-Tables," Journal of the Royal Statistical Society Series B 34 (1972):187-220.

Edwards, Martin S., "Sticking with Yes: Domestic Institutions and IMF Compliance," Working Paper, New Brunswick, NJ: Rutgers University, 2001.

Edwards, Sebastian and Guido Tabellini, "The Political Economy of Fiscal Policy and Inflation in Developing Countries: An Empirical Analysis," Policy, Research, and External Affairs Working Paper no. WPS 703, World Bank, 1991.

Freedom House. 1978-. Freedom in the World. New York: Freedom House.

Gallup, John Luke and Jeffrey D. Sachs with Andrew D. Mellinger, "Geography and Economic Development," in Boris Pleskovic and Joseph E. Stiglitz (eds.), Annual World Bank Conference on Development Economics 1998, Washington: World Bank, 1999.

Haque, Nadeem U1 and Mohsin S. Khan, "Do IMF-Supported Programs Work? A Survey of the Cross-Country Empirical Evidence," IMF Working Paper no. 98/169, 1998.

International Financial Institution Advisory Commission, Report of the International Financial Institution Advisory Commission, Washington, DC: U.S. Government Printing Office, 2000.

International Monetary Fund Annual Report, Various issues, Washington, DC: IMF.

International Monetary Fund, Evaluation of Prolonged Use of IMF Resources, Internal Evaluation Office, 2002a.

International Monetary Fund, "Guidelines on Conditionality," 2002b. 
Ivanova, Anna, Wolfgang Mayer, Alex Mourmouras and George Anayiotas, "What Determines the Completion of IMF-Supported Programs?” IMF Working Paper no. 03/8, 2003.

James, Harold, International Monetary Cooperation Since Bretton Woods, Washington, DC and New York: IMF and Oxford University, 1996.

Joyce, Joseph P., "Promises Made, Promises Broken," Wellesley College Department of Economics Working Paper \#03-04, Wellesley, MA: Wellesley College, 2003.

Kiefer, Nicholas M., "Economic Duration Data and Hazard Functions," Journal of Economic Literature 26 (1988):646-679.

Knight, Malcolm and Julio A. Santaella, "Economic Determinants of IMF Financial Arrangements," Journal of Development Economics 54 (1997):405-436.

Mellinger, Andrew D., Jeffrey D. Sachs and John L. Gallup, "Climate, Coastal Proximity, and Development," in Gordon L. Clark, Maryann P. Feldman and Meric S. Gertler (eds.), Oxford Handbook of Economic Geography, Oxford and New York: Oxford University Press, 2000.

Mody, Ashoka and Diego Saravia, "Catalyzing Private Capital Flows: Do IMF-Supported Programs Work as Commitment Devices?” IMF Working Paper no. 03/10, 2003.

Mussa, Michael and Miguel Savastano, "The IMF Approach to Economic Stabilization," in Ben S. Bernanke and Julio J. Rotemberg (eds.), NBER Macroeconomics Annual 1999, Cambridge, MA: MIT Press, 2000.

Olson, Mancur, "Autocracy, Democracy and Prosperity," in Richard T. Zeckhauser (ed.), Strategy and Choice, Cambridge, MA: MIT Press, 1991.

Overseas Development Council, The Future Role of the IMF in Development, ODC Task Force Report, Washington, DC: Overseas Development Council, 2000.

Polak, Jacques J., The Changing Nature of IMF Conditionality, Essay in International Finance no. 184, Princeton, NJ: Princeton University, 1991.

Quinn, Dennis P. and John T. Wooley, "Democracy and National Economic Performance; the Preference for Stability,” American Journal of Political Science 45 (2001):634-657, 2001.

Radelet, Steven and Jeffrey D. Sachs, "Shipping Costs, Manufactured Exports, and Economic Growth," Paper presented at AEA meetings, 1998.

Rivera-Batiz, Francisco, "Democracy, Governance, and Economic Growth: Theory and Evidence," Review of Development Economics 6 (2002):225-247. 
Roubini, Nouriel and Jeffrey D. Sachs, "Political and Economic Determinants of Budget Deficits in the Industrial Democracies," European Economic Review 33 (1989):903-33.

Royston Patrick, "Flexible Alternatives to the Cox Model," The Stata Journal 1 (2001):1-28.

Stone, Randall W. Lending Credibility: The International Monetary Fund and the PostCommunist Transition, Princeton, NJ: Princeton University Press, 2002.

Vreeland, James R., The IMF and Economic Development, New York and Cambridge, UK: Cambridge University Press, 2003. 